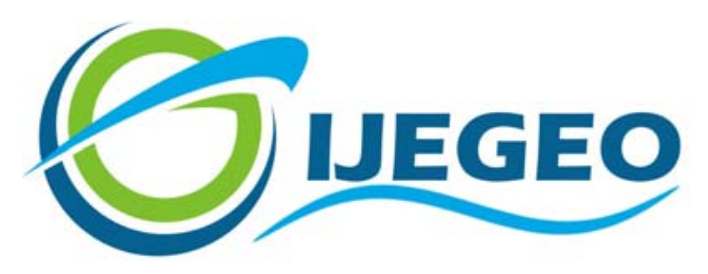

International Journal of Environment and Geoinformatics (IJEGEO) is an international, multidisciplinary, peer reviewed, open access journal.

\title{
Spatial Data Modeling Based MCE Fuzzy Logic for Petroleum Exploration in part of Say'un-Masilah Basin of Yemen
}

\section{Arafat Mohammed Bin Mohammed, Akram Javed, Mohammed Sultan Alshayef}

\section{Editors}

Prof. Dr. Cem Gazioğlu, Prof. Dr. Dursun Zafer Şeker, Prof. Dr. Ayşegül Tanık, Assoc. Prof. Dr. Şinasi Kaya

\section{Scientific Committee}

Assoc. Prof. Dr. Hasan Abdullah (BL), Assist. Prof. Dr. Alias Abdulrahman (MAL), Assist. Prof. Dr. Abdullah Aksu, (TR); Prof. Dr. Hasan Atar (TR), Prof. Dr. Lale Balas (TR), Prof. Dr. Levent Bat (TR), Assoc. Prof. Dr. Füsun Balık Şanlı (TR), Prof. Dr. Nuray Balkıs Çağlar (TR), Prof. Dr. Bülent Bayram (TR), Prof. Dr. Şükrü T. Beşiktepe (TR), Dr. Luminita Buga (RO); Prof. Dr. Z. Selmin Burak (TR), Assoc. Prof. Dr. Gürcan Büyüksalih (TR), Dr. Jadunandan Dash (UK), Assist. Prof. Dr. Volkan Demir (TR), Assoc. Prof. Dr. Hande Demirel (TR), Assoc. Prof. Dr. Nazlı Demirel (TR), Dr. Arta Dilo (NL), Prof. Dr. A. Evren Erginal (TR), Dr. Alessandra Giorgetti (IT); Assoc. Prof. Dr. Murat Gündüz (TR), Prof. Dr. Abdulaziz Güneroğlu (TR); Assoc. Prof. Dr. Kensuke Kawamura (JAPAN), Dr. Manik H. Kalubarme (INDIA); Prof. Dr. Fatmagül Kılıç (TR), Prof. Dr. Ufuk Kocabaş (TR), Prof. Dr. Hakan Kutoğlu (TR), Prof. Dr. Nebiye Musaoğlu (TR), Prof. Dr. Erhan Mutlu (TR), Assist. Prof. Dr. Hakan Öniz (TR), Assoc. Prof. Dr. Hasan Özdemir (TR), Prof. Dr. Haluk Özener (TR); Assoc. Prof. Dr. Barış Salihoğlu (TR), Prof. Dr. Elif Sertel (TR), Prof. Dr. Murat Sezgin (TR), Prof. Dr. Nüket Sivri (TR), Assoc. Prof. Dr. Uğur Şanlı (TR), Assoc. Prof. Dr. Seyfettin Taş (TR), Assoc. Prof. Dr. İ. Noyan Yılmaz (TR), Assist. Prof. Dr. Baki Yokeş (TR), Assist. Prof. Dr. Sibel Zeki (TR), Dr. Hakan Kaya (TR). 


\title{
Spatial Data Modeling Based MCE Fuzzy Logic for Petroleum Exploration in part of Say'un-Masilah Basin of Yemen
}

\author{
Arafat Mohammed Bin Mohammed ${ }^{{ }^{*}}$, Akram Javed ${ }^{2}$, Mohammed Sultan Alshayef ${ }^{3}$ \\ 1 Department of Oil \& Gas, Aden University, Yemen \\ 2,3 Department of Geology, Aligarh Muslim University, India \\ *Corresponding author \\ Tel : :902124400000 \\ E-mail : arafat.alaseri@aden-univ.net \\ Received: 01 Nov 2016 \\ Accepted: 03 March 2017
}

Abstract

GIS Provides spatial and analytical support to assess multicriteria (MCE) methods, which are used to combine data to show areas best fulfilling specific criteria. Petroleum explorations would benefit from an MCE method that is spatial, is flexible for combining heterogeneous data, considers the interpretive nature of the data, is geologically applicable, and is applicable for frontier areas or where little information exists regarding probabilities of the presence of petroleum .This study proposes a GIS-based MCE method for petroleum exploration based on fuzzy logic, which fulfills the previously stated requirements using 9 subcriteria combined to produce a favorability map of potential exploration areas. A case study applied to Sayun Almasilah Basin East Yemen. We conclude that the method can be applied in an exploration setting and, as such, is applicable for other regions of the world.

Keywords: Petroleum Exploration, Spatial Modeling, MCE, Fuzzy Logic, favorability zones

\section{Introduction}

Multicriteria evaluation (MCE) is a subset of multidimensional decision and evaluation models. Multicriteria evaluations are essentially used to evaluate the outcome of combining different criteria to fulfill one or more objectives that may possibly be conflicting (Carter, 1991; Heywood et al., 2006; Musaoğlu et al., 2012). Different methods of conducting an MCE use different criterion evaluation and score assignments, and all of them are subjective and yield different results (e.g., Heywood et al., 1995).

Multicriteria evaluation is not strictly a spatial analytical model (e.g., Saaty, 1987 Andriantiatsaholiniaina et al., 2004); however, the present study makes an attempt MCE for spatial analysis, particularly with application to economic geology settings, such as mineral or petroleum exploration. Comprehensive and indepth studies of MCE have been conducted by Voogd (1983), Carver (1991), and BonhamCarter (1994). Fuzzy logic, as presented by Bonham-Carter and supported by publications from Amin zadeh (1994), Wright and BonhamCarter (1996), and Tounsi (2005), has been selected as the MCE method for investigating petroleum favorability in this study since it is applicable for frontier areas and does not rely on prior probabilities. It has been successfully employed in mineral exploration, and economic geology; besides it is acceptable for petroleum exploration in non-spatial environment, Bingham et al., (2012). Fuzzy logic, as described by Bonham-Carter (1994), uses five operators to combine a series of data sets for a final output map. Each data set is composed of data points that are somewhere on the spectrum from not favorable to most favorable. To each of these data points, fuzzy membership values are assigned, where $0 \leq x \leq 1$ and $x$ is the fuzzy membership value, such that a value of 0 is unacceptable whereas a value of 1 is the most favorable ideal. Gradations between the two extremes reflect the expert view.

This study aims to create a method for MCE in a spatial environment that can be used for decision making support in petroleum exploration by integrating data that are spatial or tabular and can be used for analysis of data. The study proposes a data evaluation process based on a series of user- defined inputs and criteria used to show geographic areas that may be of interest for further investigation for petroleum exploration. A case study applied to Sayun- Al Masilah Basin in the central east of Yemen which is known as a mature Basin; 
however, the methodology applied and the resultant map of favorability area was verified by using ground truth data such as oil field and producing well selected for the evaluation, the favorable map was in agreement with the ground truth data. The method can be successfully applied to the frontier Basins where not much data are available.

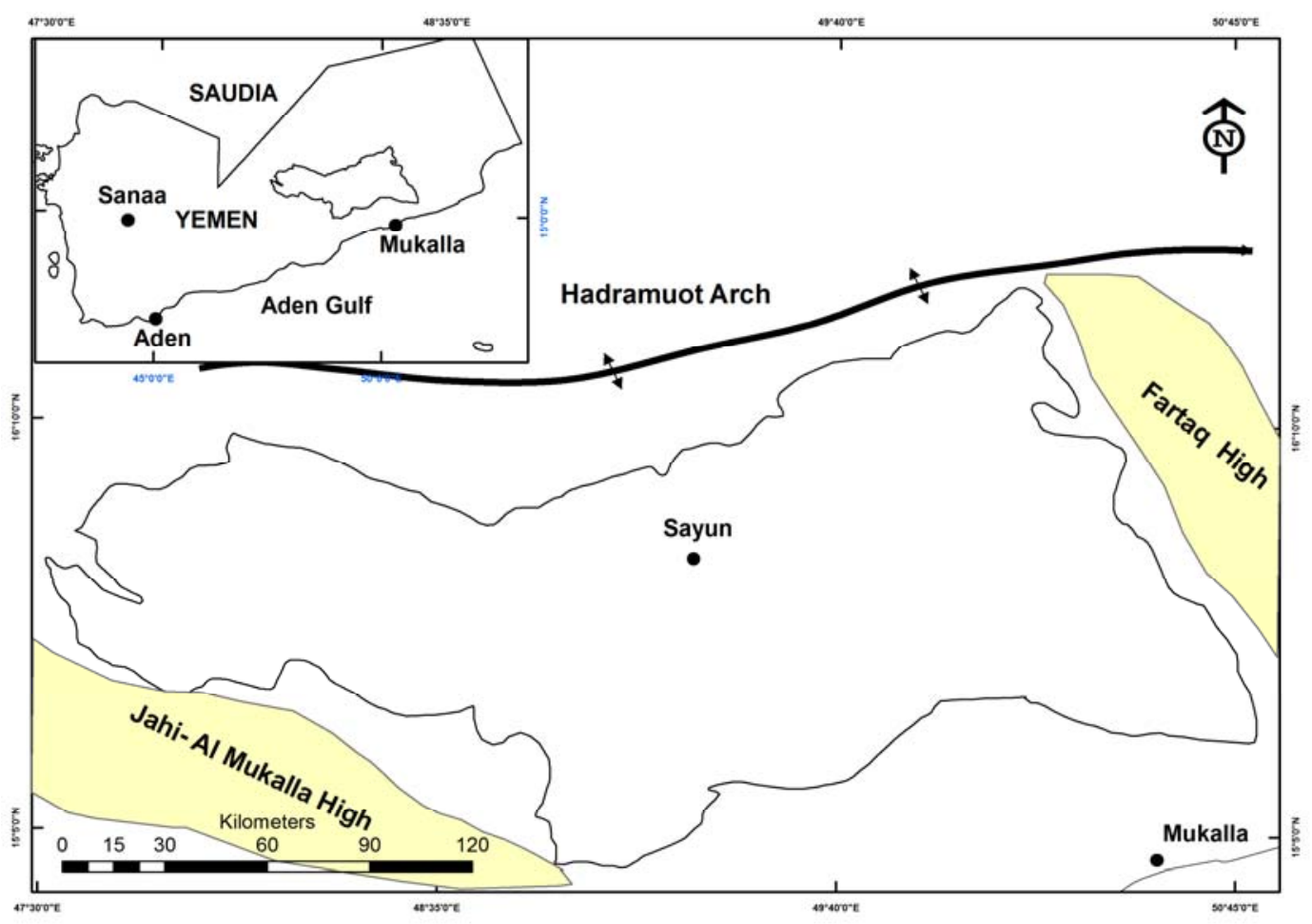

Fig 1. The study area.

\section{Study Area}

The Sayun-Al Masilah Basin is located in the Central East part of Yemen, (Fig.1), it is the second richest petroliferous basin of Yemen. The Sayun-Masila Basin is bounded from the west and southwest by the Jahi-Mukalla High, to the east by the Fartaq High, and to the north by Hadramawt Arch. This basin was formed as a rift during the Late Jurassic (Kimmeridgian) due to the Gondwana breakup (Greenwood and others, 1980; Husseini, 1989; Jungwirth and As-Sururi, 1990 Schlumberger, 1992; Redfern and Jones, 1995, Csato et al., 2001), when the African-Arabian plate was separated from the Indian-Madagascar plate (Beydoun et al., 1997). The faults have a dominant WNW-ESE trend, and approximately half of the basin is underlain by deposits more than $3000 \mathrm{msec}$ (T.W.T) thick. The sediments were deposited at the end of the Late Jurassic and continued till Tertiary age, (Beydoun et al., 1998), Csato et al., 2001). The Basin has many oil fields that were discovered by different companies

The proven source rock in this basin is organicrich shale of the Late Jurassic, Madbi Formation, (Csato and others 2001). The primary reservoir in this basin is the Lower Cretaceous Qishn Clastics, (Putnam and others, 1997).Secondary reservoir objectives are Kohlan Formation sandstone ,Saar Formation clastics and fractured basement. The Qishn Formation covers the tilted or horst blocks which were also formed during the rift stage. The above process caused the drape structure on the basement high. Some faults which were caused by reactivation after the rifting stage tend to cut the Qishn Formation. When the throw of those faults are larger than the thickness of the seal interval, it is difficult to trap the hydrocarbon in the fault related structure .Therefore, the potential of the hydrocarbon traps are controlled by the 
presence of matured source rock around the trap, and the distribution of the reservoirs and seals of each play types, such as Qishn,Saar and basement play. The Qishn reservoir interval ranges in thickness from 70 to 400 meters, thickness trends to thinner around the western area of the basin and thicker at deeper parts of the subbasins. Proven seal for the Qishn Formation is Harshyat shale, total thickness ranges from 40 to 200 meters, it is approximately 150 meter thick around the central and southern part of the basin, such thickness is adequate to provide an effective seal.

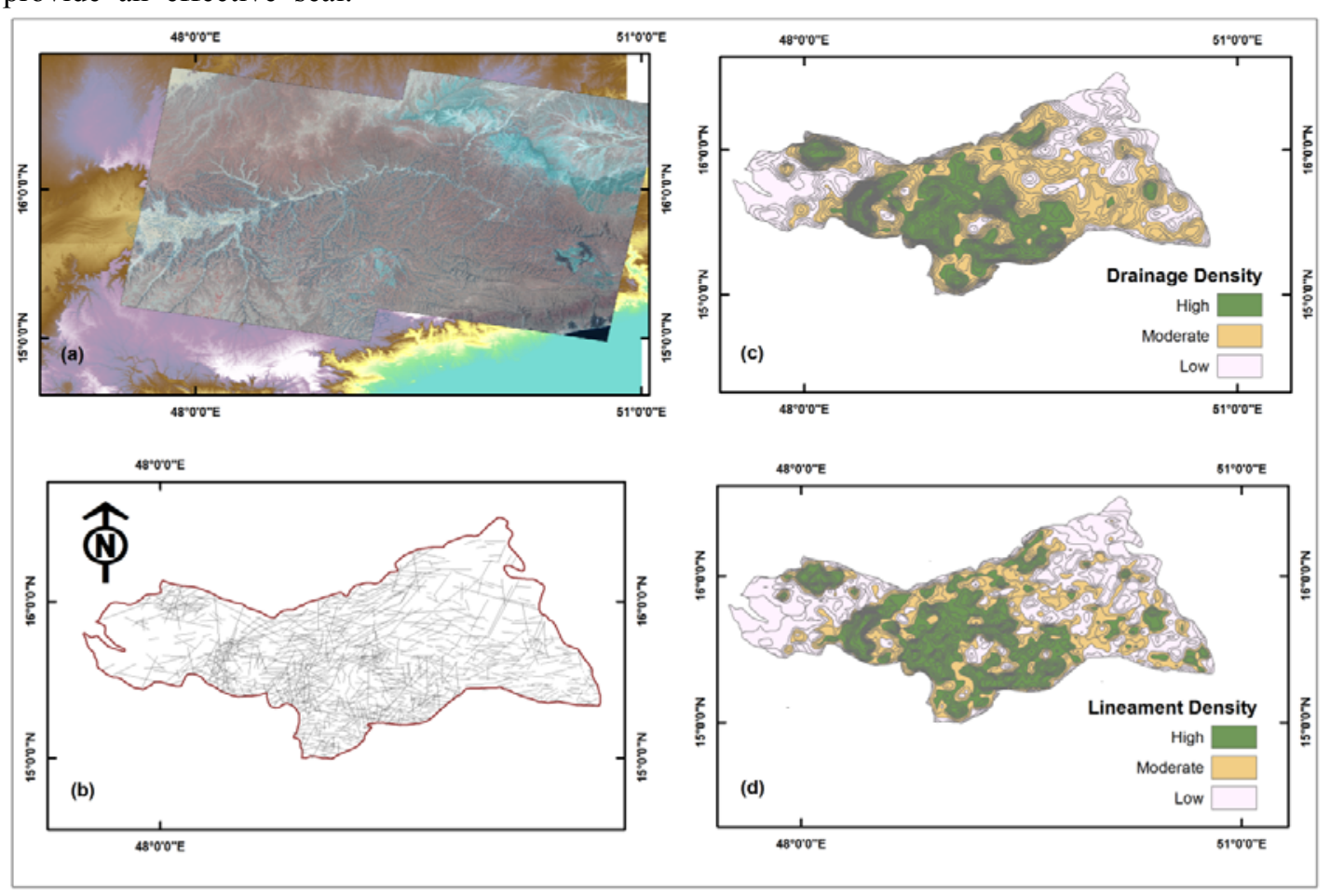

\section{Data Source and Preparation:}

In order to demarcate the favorable zones of petroleum exploration in the study area different thematic maps were prepared from remote sensing data (surface drainage anomalies, surface lineaments), Geophysical data (isopach maps, subsurface faults, top basement) and wellbores data (geothermal gradient, source rock and TOC). The following paragraphs explained the analysis applied to the data to be prepared for the main process.

Fig 2. a; shows drainage system extracted from ETM7 image and Aster GDEM image b. Lineaments map, c. Drainage Density Map (DD), D;Lineaments Density map (LD).

\section{Remote Sensing Data:}

Multidate Landsat images of ETM7( path 162,163 and row 49) covering the study area with pixel resolution $30 \mathrm{~m}$, were enhanced using image processing technique(filtering, band combination ,etc) for detecting best view of lineaments interpretations. ASTER GDEM data is useful for surface lineaments detection by using the shaded relief image technique. The study of lineaments has been applied successfully to structural geology studies and 
to Density maps using arcview3.2a. Density map is useful when combined with other data layers, finally the density map evaluated and weighted according to its importance specially when integrated with subsurface structures .Hence, Lineament and Drainage density maps classed in to three categories, (High, Moderate and Low) as shown in Fig (2.c,d)

Table 1 : details of the data used, techniques, software and resultant theme for the present study.

\begin{tabular}{|c|c|c|c|c|}
\hline Source data & Data type & process & Software used & Themes \\
\hline $\begin{array}{l}\text { ETM7 } \\
\text { (free on line) }\end{array}$ & $\begin{array}{l}\text { Two scenes } \\
\text { P162R49 } \\
\text { P163R49 }\end{array}$ & \multirow[t]{2}{*}{$\begin{array}{l}\text { Georeferencing }+ \\
\text { digitizing }+ \\
\text { density gridding }\end{array}$} & \multirow{2}{*}{$\begin{array}{l}\text { Envi } 4.3+ \\
\text { globalmapper16 } \\
+ \text { surfur13+ } \\
\text { arcview3.2+ } \\
\text { arcmap } 9.3 \\
\end{array}$} & $\begin{array}{l}\text { Lineament Density } \\
\text { (LD) }\end{array}$ \\
\hline $\begin{array}{l}\text { Aster GDem } \\
\text { (free on line) }\end{array}$ & Four scenes & & & Drainage Density (DD) \\
\hline \multirow{5}{*}{$\begin{array}{l}\text { Seismic } \\
\text { Magnetic } \\
\text { Gravity maps } \\
\text { (provided } \\
\text { from Yemeni } \\
\text { petroleum } \\
\text { exploration \& } \\
\text { production } \\
\text { Authority } \\
\text {,PEPA) }\end{array}$} & \multirow{5}{*}{$\begin{array}{l}\text { Scanned } \\
\text { Digital maps }\end{array}$} & \multirow{5}{*}{$\begin{array}{l}\text { Georeferencing }+ \\
\text { digitizing }\end{array}$} & \multirow{5}{*}{$\begin{array}{l}\text { Arcmap } 9.3 \\
\text { (digitized \& } \\
\text { georefrenced) }\end{array}$} & Qishn Isopach(QTR) \\
\hline & & & & $\begin{array}{l}\text { Harshyat } \\
\text { Isopach(HTR) }\end{array}$ \\
\hline & & & & Top Basement(BT) \\
\hline & & & & subsurface faults(SLD) \\
\hline & & & & $\begin{array}{l}\text { Source rock isopach } \\
\text { (STR) }\end{array}$ \\
\hline \multirow{3}{*}{$\begin{array}{l}\text { Boreholes } \\
\text { Data }\end{array}$} & \multirow{3}{*}{$\begin{array}{l}\text { Scanned } \\
\text { Digital maps }\end{array}$} & \multirow{3}{*}{$\begin{array}{l}\text { Georeferencing }+ \\
\text { digitizing }+ \\
\text { contouring }\end{array}$} & \multirow{3}{*}{$\begin{array}{l}\text { Arcmap 9.3+ } \\
\text { surfur13 }\end{array}$} & TOC map (TOC) \\
\hline & & & & $\begin{array}{l}\text { Geothermal gradient } \\
\text { map(GG) }\end{array}$ \\
\hline & & & & Oil fields map(OIF) \\
\hline
\end{tabular}

\section{Geophysical Data}

Different geophysical data sets obtained were in the form of hard copy maps, hence these were scanned and then digitized using arcmap 9.3 .The subsurface faults map was prepared from magnetic, gravity and seismic maps by digitizing in GIS environment. . Density map also prepared from subsurface faults map, and was subsequently categorized into three classes. Three isopach (thickness) maps of Madbi Source rock, Qishn Reservoir and Harshyat Cap rock were prepared, Madbi source map was assigned two classes (present and not present), the other two maps of Qishn and Harshyat were given three classes(High, Moderate and low).

TWT(two way time travel) structure contour of Basement Top map was digitized and classed into (High, moderate and low) .

\section{Boreholes Data:}

Geothermal gradient, total oil content (TOC) and oil field maps were contoured using surfer13, then it was exported to arcmap 9.3 with the same extension and projection of the other themes. Geothermal map given two class (High, and Low), TOC map was given three classes(High, Intermediate and Low) and oil field map was given two classes( present, not present). Table 1 summarized the process and the result maps.

\section{Methodology:}

The methodology for the present study has five broad steps (Fig 3). Firstly, the data were prepared as vector maps, then it was evaluated and classed, then the main criteria were defined and categorized as different sub criteria then those criteria and sub criteria were converted in to raster maps. The raster maps were assigned fuzzy membership values and the Fuzzy membership (FM) maps were evaluated for the final process. Finally, the criteria and sub criteria (FM) maps were combined to locate the favorable zone for oil exploration using Fuzzy Logic operators. The final favorable map was evaluated with ground truth data for the validation of the result map. The fuzzy logic operators are (Fuzzy AND, Fuzzy OR, Fuzzy algebraic Sum, Fuzzy algebraic Product and Gamma operator) 
summary of operators definition mentioned below:

Fuzzy AND: This is the equivalent to a Boolean AND(logical intersection) operation on classical set values

$\mu_{v}=\operatorname{MIN}\left(\mu_{A}, \mu_{B}, \mu_{C}, \ldots . ., n\right)$

Fuzzy OR :this is equivalent to a Boolean OR (logical union) on classical set values

$\mu v=\operatorname{MAX}\left(\mu_{A}, \mu_{B}, \mu_{C}, \ldots ., n\right.$

Fuzzy Algebraic Product: the combined membership function is defined as

$\mu_{v}=\prod_{i=1}^{n_{i=1} i}$

Where $\mu \mathrm{i}$ is the fuzzy membership function for the $\mathrm{i}$ map, $\mathrm{i}=1,2,3 \ldots \ldots, \mathrm{n}$ maps are to be combined .The Fuzzy membership values tend to be very small with this operator, due to the effect of multiplying several numbers less than 1.nevertheless ,all the contributing membership values have an effect on the result, unlike the fuzzy AND or Fuzzy OR operators.

Fuzzy Algebraic Sum: this Operator is complementary to the Fuzzy product, being defined as

$\mu_{v}=\left(1-\prod_{i=1}^{n_{i}[1-\mu i]}\right.$

The result is always larger (or equal to) the largest contributing fuzzy membership value. The effect is therefore "increasive". The "increasive" effect of combining several favorable pieces of evidence is automatically limited by the maximum values of (1.0). Fuzzy algebraic product is an algebraic product but Fuzzy algebraic sum is not an algebraic summation.

$$
\mu_{v}=\left(1-\prod_{i=1}^{n_{i=1}^{[1-\mu i] n}}\right)^{\gamma}\left(\prod_{i=1}^{\mu i}\right)^{(1-\gamma)}
$$

Where, $\mathrm{\gamma}$ is a parameter chosen in the range $(0,1)$.when $y$ is 1 the combination is same as fuzzy algebraic sum, and when $\gamma$ is 0 the combination is equal to the fuzzy algebraic product. Judicious choice of the $\mathrm{y}$ produces output values that ensure flexible compromise between the "increasing" tendencies of the Fuzzy algebraic sum and the "decreasing" effects of the fuzzy algebraic product.

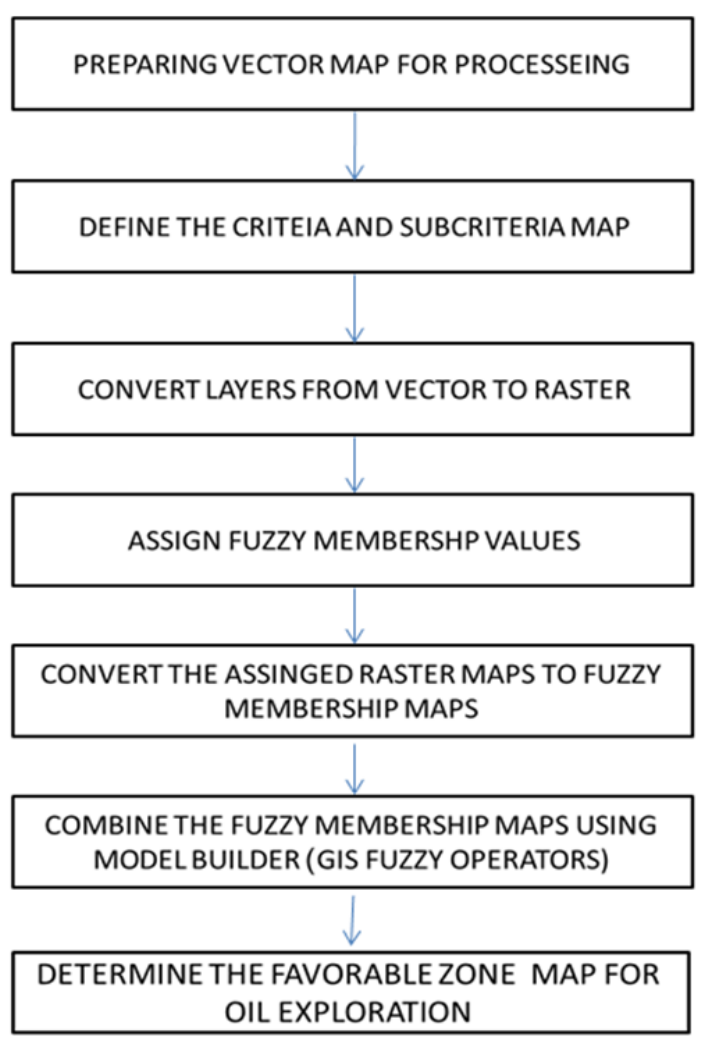

Fig.3. shows the methodology flow chart.

\section{Defining the Criteria}

Three main criteria can be summarized as (1) Criteria-A (2) Criteria-B, and (3) Criteria-C. The sub criteria will be defined as below.

3.1.1 Criteria-A:

The criteria-A, focused on the surface anomalies such as Lineaments and drainage density map of the study area, these anomalies show strong relation with the subsurface Basement structures,(Arafat et al., 2010; 2011).

Most of the derived surface anomalies are in agreement with the location areas of oil fields and leads, therefore three sub criteria were combined, Lineament density (LD), drainage Density (DD)and subsurface Lineament Density(SLD). Hence, subsurface lineament 
density map was combined with surface Lineament and drainage density maps; this combination was done to show how strongly the surface anomalies (Lineament and Drainages) are controlled by subsurface structures. Hence, the results of this integration strongly support the area of structural traps. Most of the reservoirs within Sayun- AlMasilah Basin are of structural type, which is corroborated from the available literature..

\section{Criteria-B:}

The geophysical maps provide a better understanding of the subsurface structures. Hence, the time structure of Basement Top (BT), Qishn Isopach (QTR), Harshyat Isopach (HTR), and Madbi source Isopach (MTR) maps were used in these criteria. Sub criteria layers classed according to their importance (Table2).

\section{Criteria-C:}

Around 34 exploration well data covering the sedimentary Basin provided from the Yemeni authority, the well data ranges between producing and Dry wells, different information were extracted and mapped such as total oil content (TOC), geothermal gradient(GG) . Generally two sub criteria layers were prepared and classed according to their importance, (Table2).

After the defining of the criteria and sub criteria, the final format for analysis depends on two factors: the nature of the data (raster, vector) and the type of MCE analysis .Fuzzy logic requires the use of map algebra, which is not applicable on vector data sets unless those data sets are converted to a raster. The most appropriate method for making the vector to raster conversion must be established based on the map scale of the analysis, which will influence the cell size of the raster and any vector to raster conversion methods.

At the end of this step, all data should be in a uniform GIS-based format with appropriate semantically consistent attributes. Furthermore, all data should be in the same projection and should have the same grid spacing (Sawatzky et al., 2009) .In this step all the (vector) maps were converted to raster maps, using spatial conversion tool (vector to raster) of arcmap 9.3.
The resulted maps from conversion were given same pixel size (100) and image extension (Esri grid) with (UTM Zone $39 \mathrm{~N})$ projection. Figure 4 shows the 9 sub criteria after the conversion was applied using feature to raster convert of GIS spatial analyst tool.

Fuzzy membership (FM) assigned to thematic classes:

The Fuzzy membership values have been assigned to different thematic raster maps according to their classification in respect of oil exploration contribution. Different classes have been given the weightage by the different experts. All the expert weightage has been converted in the fuzzy membership maps according to their fuzzy membership values within the range of (0.1-1.0).

\section{Model Build up Based Fuzzy Logic Operation:}

After the criteria has been selected and the fuzzy membership values have been assigned, creating a conceptual model on how these criteria and sub criteria will interact is important by choosing fuzzy-logic operators.

This section demonstrates the results of combining the data at the criteria of higher levels .Using the Spatial Data Modeler (Sawatzky et al, 2009), a model was built in ArcGISTM 9.3 using the model builder (Fig. 5.)

The model represents all sub criteria layers to have a regional favorability map. Fuzzy logic operation process applying the equations described in section (3). The results are a series of maps showing favorability for petroleum exploration for each criterion from equation (2) and (5). The final result, which is used for the evaluation, is the map from equation (5).

Hence, the criteria-A map combines sub criteria using Gamma operation equation (5) by giving Gamma value equal to $(0.80)$ which produces increasive output result map (SLLDD) showing fuzzy membership values range (0.08 to 1.0) (Fig6.a). 
(a)

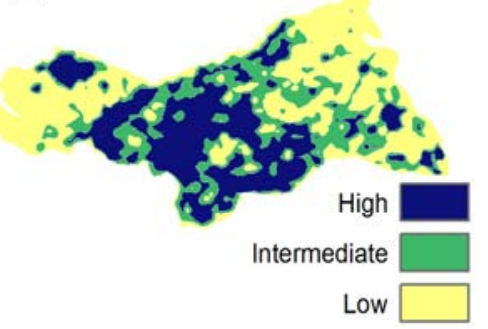

(b)

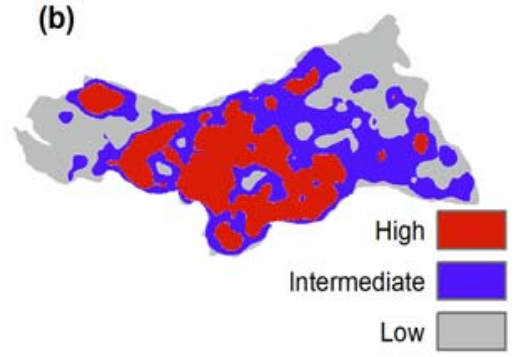

(c)

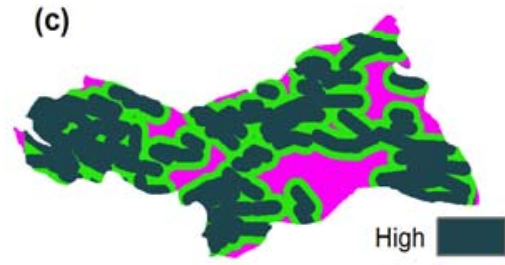

Intermediate

Low

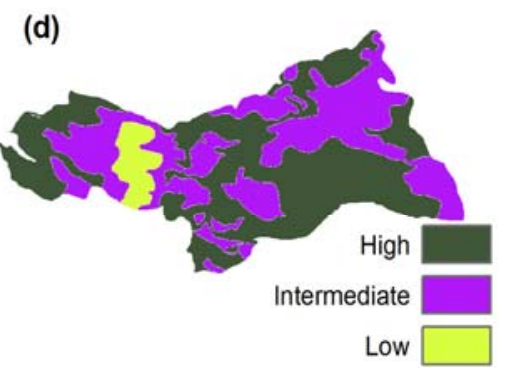

(e)

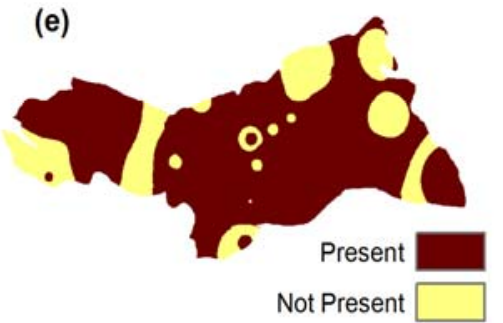

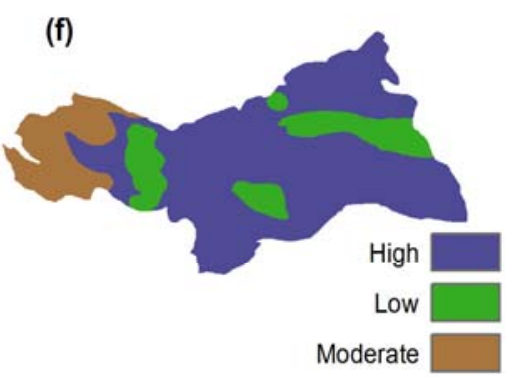

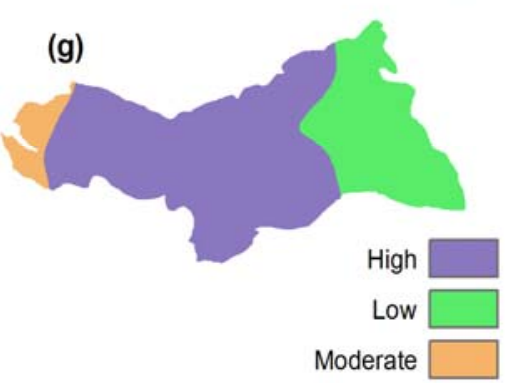

(h)
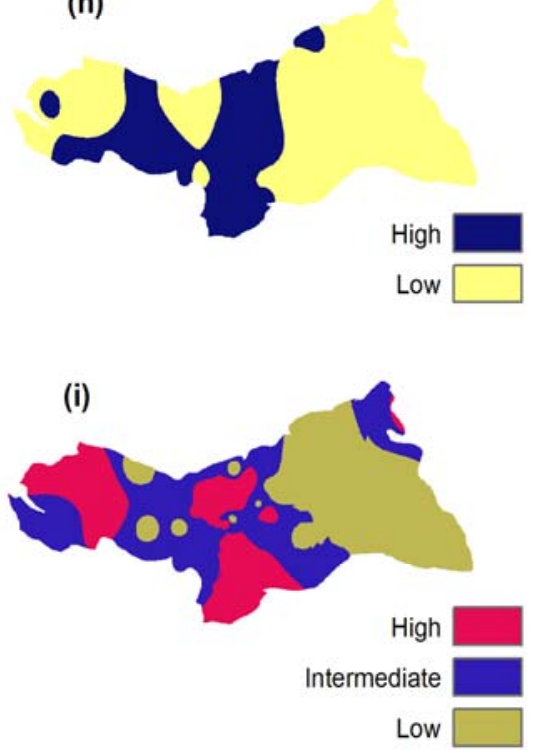

Fig 4. Shows raster maps with their classes, (a) surface lineament density (SLD), (b) drainage density (DD), (c) subsurface lineament density (SLD), (d) basement top (BT), (e) Madbi thickness rock (MTR), (f) Qishn thickness rock (QTR), (g) Hrashyat thickness rock (HTR), (h) geothermal gradient (GG),( i) total oil content (TOC). 
Table 2. shows the criteria and sub criteria and attribute with fuzzy membership values.

\begin{tabular}{|c|c|c|c|}
\hline Criteria & Sub criteria & Attribute & $\begin{array}{c}\text { Fuzzy membership Values( } \\
\text { FM) }\end{array}$ \\
\hline \multirow[t]{9}{*}{$\mathrm{A}$} & \multirow{3}{*}{$\begin{array}{l}\text { Surface Lineament } \\
\text { Density(LD) }\end{array}$} & High & 1.0 \\
\hline & & Intermediate & 0.5 \\
\hline & & Low & 0.1 \\
\hline & \multirow[t]{3}{*}{ Drainage Density(DD) } & High & 1.0 \\
\hline & & Intermediate & 0.5 \\
\hline & & Low & 0.1 \\
\hline & \multirow{3}{*}{$\begin{array}{l}\text { Subsurface Lineament } \\
\text { Density(SLD) }\end{array}$} & High & 1.0 \\
\hline & & Intermediate & 0.5 \\
\hline & & Low & 0.1 \\
\hline \multirow[t]{11}{*}{ B } & \multirow[t]{3}{*}{ Basement Top(BT) } & High & 1.0 \\
\hline & & Intermediate & 0.5 \\
\hline & & Low & 0.1 \\
\hline & \multirow[t]{3}{*}{ Qishn Isopach(QTR) } & High & 1.0 \\
\hline & & Intermediate & 0.5 \\
\hline & & Low & 0.1 \\
\hline & \multirow[t]{3}{*}{ Harshyat Isopach(HTR) } & High & 0.7 \\
\hline & & Intermediate & 0.3 \\
\hline & & Low & 0.1 \\
\hline & \multirow[t]{2}{*}{ Madbi Source(MTR) } & Present & 1.0 \\
\hline & & Not Present & 0.1 \\
\hline \multirow[t]{5}{*}{$\mathrm{C}$} & \multirow[t]{3}{*}{ TOC } & High & 0.9 \\
\hline & & Intermediate & 0.5 \\
\hline & & Low & 0.1 \\
\hline & \multirow{2}{*}{$\begin{array}{c}\text { Geothermal } \\
\text { Gradient(GG) }\end{array}$} & High & 1.0 \\
\hline & & Low & 0.1 \\
\hline
\end{tabular}




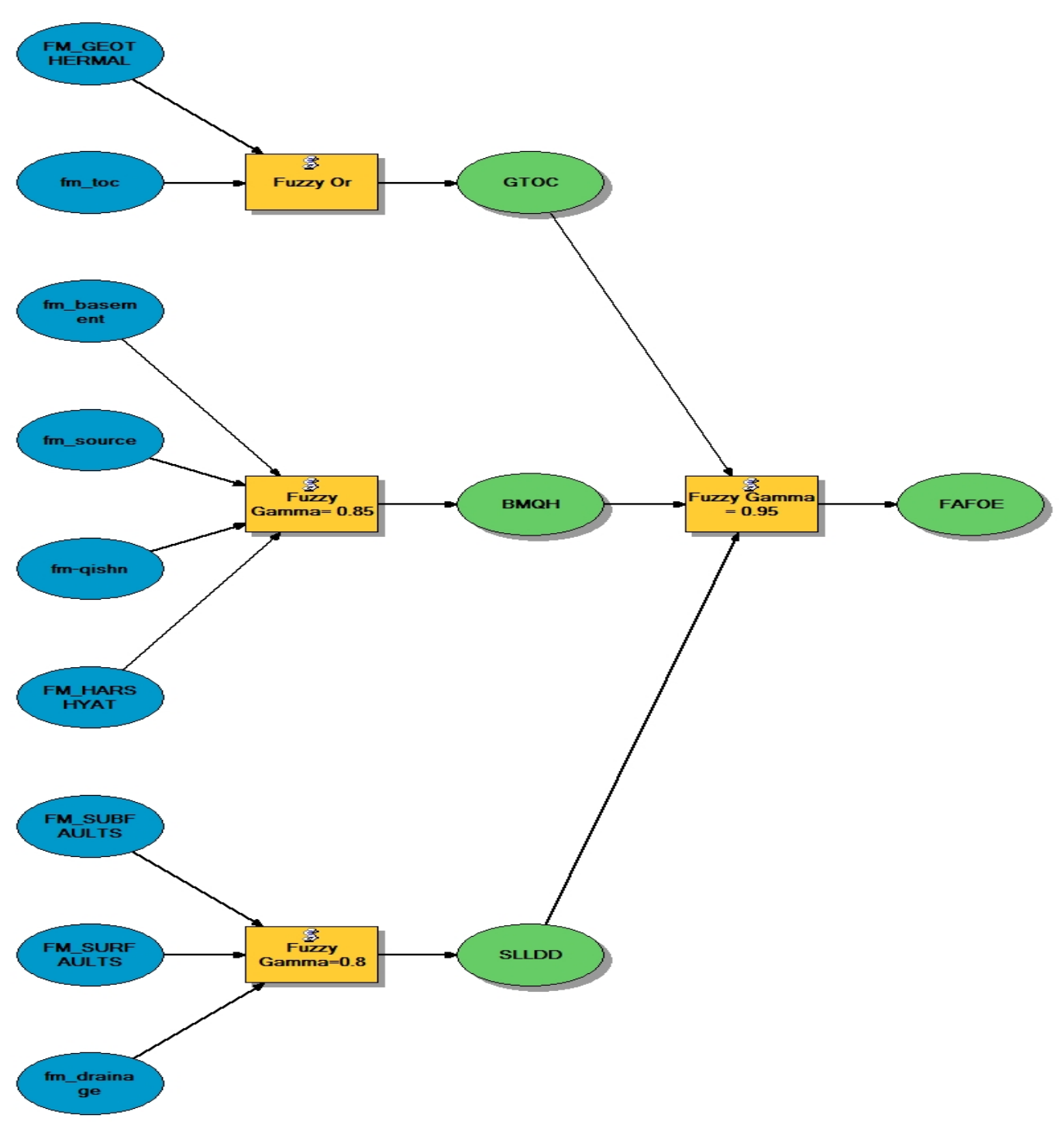

Fig 5. Flow chart of the model builder that applied to the subcriteria maps.

The criteria-B map combines sub criteria using the Gamma value equal to (0.85) and applying equation(5).The resultant map (BTMQH) showing fuzzy membership values range( 0.27 to 0.94), (Fig.6.b), shows that black color zones indicating a high favorability.

The criteria-C map combines sub criteria using the algebraic (OR) and applying equation(2), the resultant map (GTOC) showing fuzzy membership values range( 0.1 to 1.0$)$, $(\mathrm{Fig}(6 . \mathrm{c})$. Finally the three derived maps from above combination (SLLDD, BTMQH and GTOC) were combined using a gamma value equal to
(0.95) and applying equation(5). It is suggested that the gamma value would be near (0.95) because this value will probably be increasive and will reflect the decisionmaking process of a geologist (BonhamCarter, 1994). Previous models used 0.95 and 0.975 for geologic models (An and others, 1991),Wright and BonhamCarter,1996). The result of the combination reflected an increasive valued map (FAFOE) showing fuzzy membership values range (0.31 to 0.99$)$, as shown in fig (6.d), indicating highly favorable zone for oil exploration. 

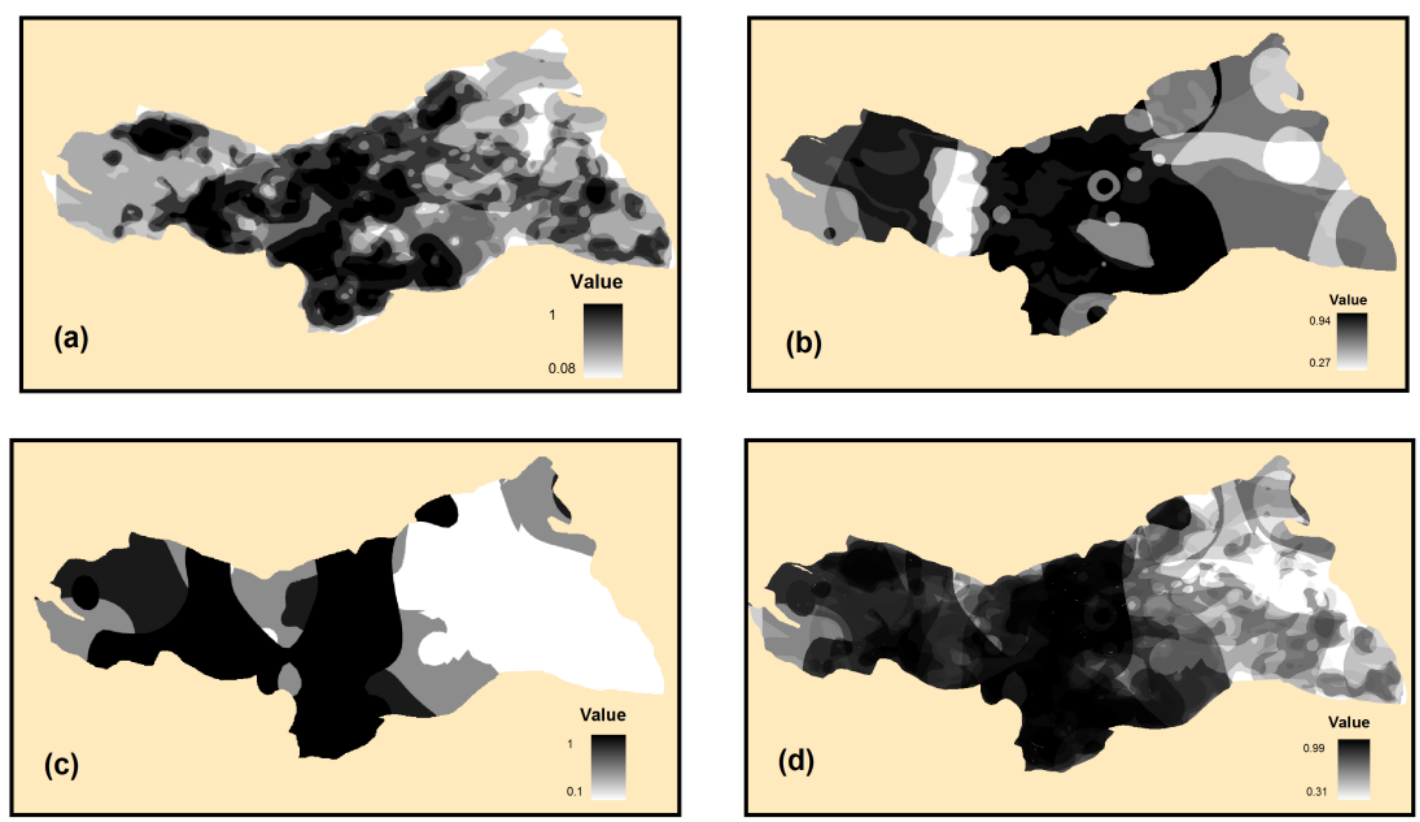

Fig 6. shows the result criteria map from the fuzzy logic combinations, A; the SLLDD criteria map result from combination LD,DD,SLD sub criteria, B; the BTMQH criteria map result from combination BT,MTR,QTR,HTR sub criteria ,C; the GTOC criteria map result from combination GG,TOC sub criteria, $D$; the FAFOE criteria map result from combination SLLDD,BTMQH,GTOC favorable maps.

\section{Validation of outcome:}

The final favorability map was derived, and categorized into five classes, i.e. extremely Favorable with fuzzy membership values 0.95 to 0.99 (class 1), favorable with fuzzy membership values 0.87 to 0.95 (class 2), Moderate favorable with fuzzy membership values 0.76 to 0.87 (class 3) less favorable with fuzzy membership values 0.62 to 0.76 , (class 4 ) and the last unfavorable with fuzzy membership values 0.31 to 0.62 (class 5). This classified map can be compared to known oil production locations in the basin. Three oil fields and six producing wells were chosen for the verification and validation of the outcome, as shown in fig. 7 . out of 6 wells 5 wells were found in area with black color that classed as extremely favorable zone, this zone covers an area around $\left(9166.65 \mathrm{~km}^{2}\right)$, also it is observed that out of 3 oil fields 2 oil fields are located in the zone of extremely favorability as well as the oil wells, while one oil field located in zone classed as favorable zone shown in dark grey color, this zone covers an area of around $\left(3686.24 \mathrm{~km}^{2}\right)$. Hence, we can suggest that our assumption for the assigning fuzzy membership values to the sub criteria maps shows an optimum approach specially the selected logic operators and the assigning values to the gamma as well as the success in defining and evaluation the criteria and sub criteria. 


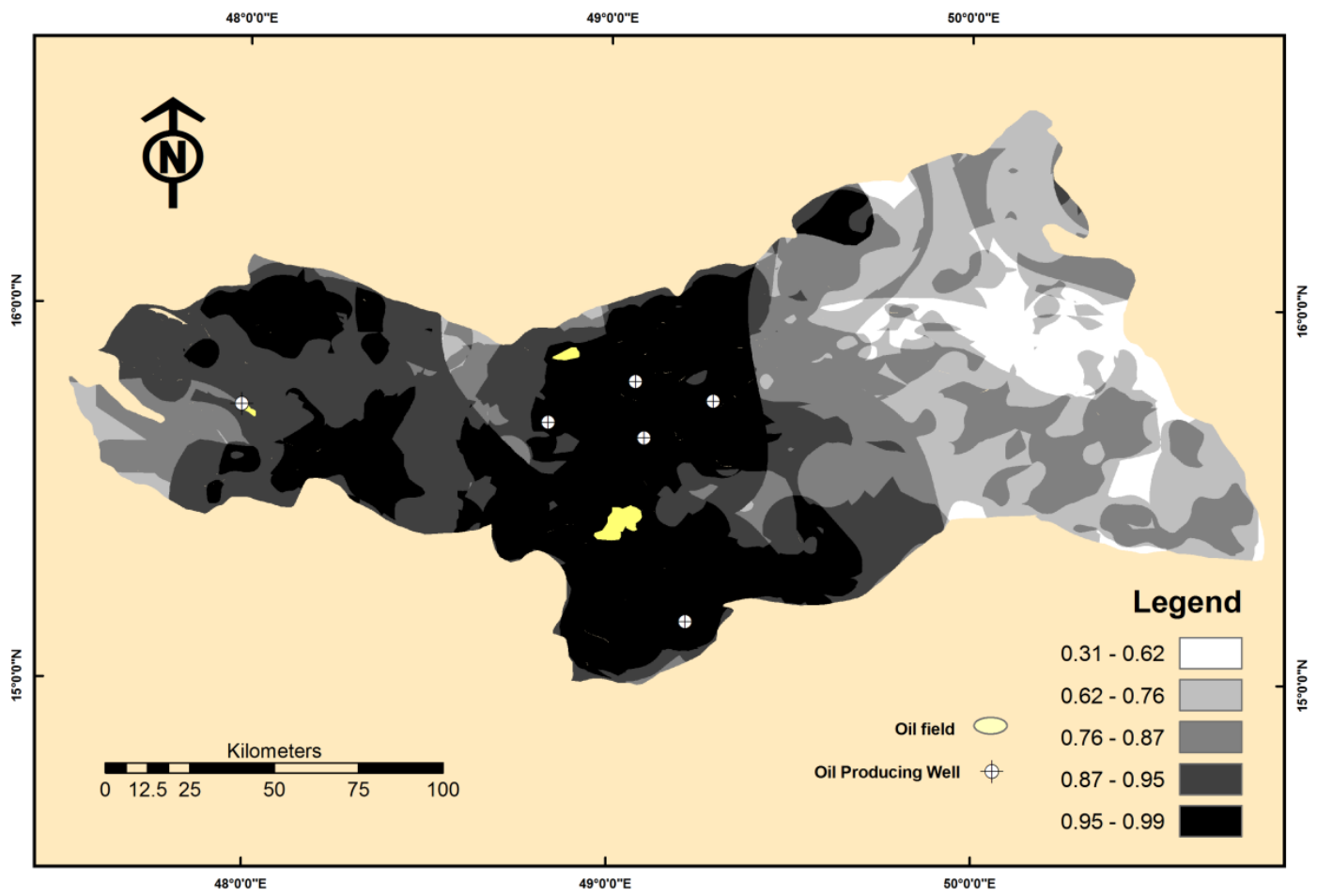

Fig 7. The final favorability map for oil exploration with oil fields and produced wells locations draped over FAFOE map for the validation of the model applied.

\section{Conclusion}

The present study demonstrates the utility of remote sensing data and its integration with other physical and structural data in GIS domain to demarcate the potential areas of oil and gas exploration. The achieved results have manifested the oil-gas potential zones, which were detected through the use of GIS MCE based Fuzzy logic, and were subsequently validated. The study logically proves that almost all of the known oil-gas discovered wells coincided with the extremely favorable zones in the Sauyn - Al Masilah Basin .MCE based fuzzy logic is a new approach that can be applied in oil-gas exploration in the frontier Yemeni Basins. The results presented in this paper prove the significance and importance of the approach in delineating oil-gas favorable zones, especially in areas which have limited data. The approach adopted in the study seems to be the most time and cost effective besides it has a considerably high accuracy which may be replicated in other petroliferous basins of the world.

\section{References}

Aminzadeh, F. (1994). Applications of fuzzy expert systems in integrated oil exploration: Computers and Electrical Engineering, Vol: 20: 89-97.

An, P., W. M. Moon, and A. Rencz (1991). Application of fuzzy set theory for integration of geological, geophysical and remote sensing data, Canadian Journal of Exploration Geophysics, vol. 27: 1-11.

Andriantiatsaholiniaina, L., V. S. Kouikoglou, and Y. A. Phillis. (2004). Evaluating strategies for sustainable development:Fuzzy logic reasoning and sensitivity analysis: Ecological Economics, vol.48: 149-172.

Arafat M. M., Palanivel K, Kumanan C.J, Ramsamy SM. (2010). Significance of surface lineaments for oil and Gas Explorations in part of Sabatayn Basin, Yemen, Journal of Geography and Geology, Vol.2(1): 119-228.

Arafat M. M., Palanivel K, C.J. Kumanan, SM Ramsamy (2011). Spatial Analysis of Geosystem Parameters for Hydrocarbon 
Prospecting in part of Yemen, Journal of Geomatics ,Vol.5(1): 25-29.

Arlegui, L. E., Soriano, M. A. (1998). Characterizing lineaments from satellite images and field studies in the central Ebro basin (NE Spain), International Journal of Remote Sensing vol.19: 3169-3185.

Beydoun, Z.R. (1997). Introduction to the revised Mesozoic stratigraphy and nomenclature for Yemen, Marine and Petroleum Geology, Vol:14(6): 617-629.

Beydoun, Z.R., A.L. As-Saruri, Mustafa, ElNakhal, Hamed, Al-Ganad ,I.N., Baraba, R.S., Nani, A.S.O., and Al-Aawah, M.H. (1998). International lexicon of stratigraphy, Volume III, Republic of Yemen, Second Edition: International Union of Geological Sciences and Ministry of Oil and Mineral Resources, Republic of Yemen Publication $34,245 \mathrm{p}$.

Bingham L., Zurita M. R., and Escalona A., Geographic information system-based fuzzy-logic analysis for petroleum exploration with a case study of northern South America, American Association Petroleum Geologists. AAPG Bulletin, vol.96, no.11 (November 2012), p.21212142.

Bonham-Carter, G. F. (1994). Geographic information systems for geoscientists modeling with GIS: Computer methods in the geosciences: Oxford, Pergamon, 398 p.

Carter,S.,1991,Site search and multicriteria evaluation: Planning Outlook, Vol.34:2736.

Carver, S. J. (1991). Integrating multicriteria evaluation with geographical information systems: International Journal of Geographical Information Systems, vol.5: 321-339.

Csato, I., Habib, A., Kiss, K., Kocz, I., Kovacs, Z., Lorincz, K., and Milota ,K. (2001). Play concepts of oil exploration in Yemen, Oil and Gas Journal, Vol. 99(23): 68-74.

Greenwood, W.R., Anderson, R.E., Fleck, R.J., and Roberts, R.J. (1980). Precambrian geologic history and plate tectonic evolution of the Arabian Shield, Directorate General of Mineral Resources, Ministry of Petroleum and Mineral Resources, Jiddah, Saudi Arabia, Bulletin 24, 35p.

Heywood, I., J. Oliver, and S. Tomlinson. (1995). Building an exploratory multicriteria modeling environment for spatial decision support: Innovations in GIS, Vol.2:127-136.

Heywood, I., S. Cornelius, and S. Carver (2006). An introduction to geographical information systems: Harlow, England, Pearson Prentice Hall, 426p.

Husseini, M.I., 1989, Tectonic and deposition model of Late Precambrian-Cambrian Arabian and adjoining plates,American Association of Petroleum Geologists Bulletin, Vol. 73: 1117-1131.

Jungwirth, J., and As-Saruri, M. (1990). Structural evolution of the platform cover on southern Arabian Peninsula (P.D.R. Yemen), Zeitschrift fur Geologische Wissenschaft, Vol. 18: 505-514.

Lalor, J. H. (1986). The Olympic Dam copperuranium-gold deposit, South Australia, Transactions Fourth Circum-Pacific Energy and Mineral Resources Conference, Singapore.American Association Petroleum Geologists. Tulsa ,Oklahoma: 561-567.

Mostafa, M., Zakir, F. (1996). New enhanced techniques for azimuthal analysis of lineaments for detecting tectonic trends in and around the Afro-Arabian Shield, International Journal of Remote Sensing, vol.17:.2923-2943.

Musaoğlu, N., Saral, A. and Şeker, DZ. (2012). Designing a Software for Flood Risk Assessment Based on Multi Criteria Desicion Analysis and Information Diffusion Methods, American Geophysical Union, Fall Meeting 2012

O'Driscoll, E. S. T. and Campbell, I. B. (1997). Mineral deposits related to Australian continental ring and rift structures with some terrestrial and planetary analogies, Global Tectonics and Metallogeny Vol.6: 83-101.

Putnam, P.E., Kendall, G., and Winter, D.A., (1997). Estuarine deposits of the Upper Qishn formation (Lower Cretaceous), Masila region, Yemen , American Association of Petroleum Geologists Bulletin, Vol. 81(8): 1306-1329.

Redfern, P. and Jones, J.A. (1995). The interior rifts of Yemen Analysis of basin structure and stratigraphy in a regional plate tectonic context, Basin Research, Vol. 7: 337-356.

Saaty, R. (1987). The analytical hierarchy process: What it is and how it is used:Mathematical Modeling, Vol.9: 161176. 
Sawatzky, D. L., G. L. Raines, G. F. BonhamCarter, and C. G.Looney. (2009). Spatial data modeller (SDM): ArcMAP 9.3geoprocessing tools for spatial data modeling using weights of evidence, logistic regression, fuzzy-logic and neural networks:

Schlumberger (1992). Looking for Yemen's hidden treasure, Middle East Well Evaluation Review, No.12: 12-20.

Suzen, M. L., Toprak, V. (1998). Filtering of satellite images in geological lineament analyses: an application to a fault zone in Central Turkey, International Journal of Remote Sensing, Vol.19: 1101-1114.

Tounsi, M. (2005). An approximate reasoningbased technique for oil assessment: Expert Systems with Applications, Vol. 29: 485491.

Voogd, H. (1983). Multicriteria evaluation for urban and regional planning: London, United Kingdom, Pion Limited, 367p.

Woodall, R. (1993). The multidisciplanary team approach to successful mineral exploration, Society of Economic Geologists Newsletter 14:1-6.

Woodall, R. (1994). Empiricism and concept in successful mineral exploration, Australian Journal of Earth Sciences 41(1): 1-10.

Wright, D. F., and G. F. Bonham-Carter. (1996). VHMS favorability mapping with GIS-based integration models, Geological Survey of Canada Bulletin 426: 339-376.

Zakir, F., Qari, M., Mostfa, M. (1999). A new optimising technique for preparing lineament density maps, International Journal of Remote Sensing, Vol.20: 10731085. 